\title{
Larval polychaetes are strongly associated with marine snow
}

\author{
Alan L. Shanks ${ }^{1, *}$, Kimberly A. del Carmen ${ }^{2}$ \\ ${ }^{1}$ Oregon Institute of Marine Biology, University oi Oregon, PO Box 5389, Charleston, Oregon 97420, USA \\ ${ }^{2}$ Pacific Biomedical Research Center, Kewalo Marine Laboratory, University of Hawaii, 41 Ahui St., Honolulu, Hawaii 96813, USA
}

\begin{abstract}
The association of larval polychaetes with marine snow was investigated (1) with SCUBA to sample marine snow in the field and (2) in laboratory experıments. The field sampling took place in the Atlantic Ocean off Charleston, South Carolina, USA (3 sample dates) and in the Pacific Ocean at 2 locations around the San Juan Islands, Washington, USA ( 7 sample dates). On all of the sample dates marine snow was present and abundant (range 1 to $63 \mathrm{agg} . \mathrm{l}^{-1}$ ). Larval polychaetes were significantly concentrated on aggregates on 7 of the 10 samplc dates. Larval polychaetes from 12 families were present in the plankton samples of which 10 familes were found associated with aggregates. On average, $16 \%(\mathrm{SD}=22 \%$ ) of all larval polychaetes were on aggregates. Precompetent and competent larval polychaetes made up 84 and $16 \%$ respectively of the larval polychaetes in the plankton. On average $20 \%$ of all precompetent polychaete larvae were on aggregates. In contrast, competent polychaete larvae were strongly associated with aggregates with $80 " \ldots$ of the competent larval polychaetes on aggregates. Laboratory experiments using 4 polychaete species and laboratory-made marine snow also found that larval polychaetes were concentrated on aggregates. In a vertical flume, observations were made on the behavior of larval polychaetes following contact with aggregates. Upon contacting marme snow, larval polychaetes crawled into or over the surface of aggregates for several minutes before swimming away. These field and laboratory observations suggest that a precompetent polychaete larva might spend about $5 \mathrm{~h} \mathrm{~d}^{-1}$ visiting aggregates and that during a day it may visit about 90 aggregates. Competent larval polychaetes may spend $>19 \mathrm{~h} \mathrm{~d}^{-1}$ on aggregates. Polychaete larvae visiting or residing on aggregates may be feeding on the aggregate microbial community. Further, the vertical flux and, perhaps, benthic deposation of larvae residing in aggregates is due to the sinking of the marine snow. Clearly, marine snow is an important component of the environment for many types of polychaete larvae and adaptations to life in aggregates may have played a role in the evolution of polychaete larval traits.
\end{abstract}

KEY WORDS: Marine snow Polychaetes Larvae Aggregates - Meroplankton Competent Precompetent - Settlement

\section{INTRODUCTION}

In a liter of fresh- or seawater the planktonic organisms are generally assumed to be randomly distributed in space; that is, we assume that biological or physical structure in these environments do not impose fine scale order on the distribution of organisms. This traditional view of the planktonic world is perhaps an artifact of the sampling techniques researchers have historically used. Plankton are collected with water

\footnotetext{
-E-mail: ashanks@oimb.uoregon.edu
}

sampling bottles which 'grab' a volume of water, or with plankton nets which filter a larger volume of water and concentrate the trapped organisms into a collection bucket. Consequently, any fine scale biological or physical structure in the environment is destroyed during sampling; the sampling technique dictates the world view of the biologist.

Shortly after people began to enter the pelagic realm in submersibles (Tsujita 1952, Suzuki \& Kato 1953) or as divers (Hamner et al. 1975) it became apparent that plankton are not necessarily randomly distributed in the water column. For example, using SCUBA, Omori \& Hamner (1982) observed dense aggregations of a 
variety of zooplanktors, aggregations which were 100 to 1000 times more concentrated than the average population density as indicated by a plankton tow. Further, in all marine and freshwater environments in which researchers have looked, they have found macroscopic aggregations of detritus and microbes (e.g. marine snow, lake snow or aggregates), which provide a structured benthic-like micro-habitat in the water column (Alldredge \& Silver 1988, Kiorboe et al, 1990, Grossart \& Simon 1993, Kiørboe 1996). The concentrations of detritus and microbes within aggregates are generally much higher than concentrations in the surrounding aggregate-free water (Alldredge \& Silver 1988).

Marine snow is not only ubiquitous in the ocean and has been observed in at least 1 lake, it is often quite abundant. In estuarine waters concentrations of marine snow can be $>100 \mathrm{l}^{-1}$ (Wells \& Shanks 1987), while in coastal waters concentrations are usually around 1 to $10 !^{-1}$ (Alldredge \& Silver 1988). In Lake Constance (Germany) aggregate concentrations were generally on the order of $10 \mathrm{l}^{-1}$ (Grossart \& Simon 1993). In the ocean, many benthic invertebrates produce larvae which spend days to months in the plankton. Given the abundance of marine snow it seems inevitable that the larvae of benthic invertebrates will contact aggregates. What happens when a larva contacts an aggregate? Do larvae swim away following contact or do they remain with the aggregate exploiting it as a food source or habitat?

Shanks \& Edmondson (1990) made the first observations on the association of meroplankton with aggregates. They made observations on 4 dates at Cape Lookout Bight, North Carolina, USA. They found that 9 and $74 \%$ respectively of the precompetent and competent larval polychaetes were associated with aggregates. On average $80 \%$ of the vertical flux of competent larvae through the water column was due to larvae associated with aggregates. In a later study, Bochdansky \& Herndl (1992) found larval polychaetes associated with aggregates sampled in the northern Adriatic Sea. Their observations further suggested that larval polychaetes may have been feeding on the detritus and microbes in aggregates. Most recently, Green \& Dagg (1997) found larval polychaetes to be associated with marine snow collected in the Gulf of Mexico.

In this study we further investigate the association of larval polychaetes with marine snow. The previous studies took place in 3 locations and one might assume that the association of larval polychaetes with aggregates is a phenomena peculiar to these locations. By sampling additional locations and in a new ocean, we greatly expanded the conditions under which one can expect to find polychaete larvae associated with marine snow. The number of aggregates collected per sample was larger in this study than in the previous studies. This allowed for a more detailed analysis of the taxonomic composition of the larvae in aggregates and their relative stage of development.

\section{METHODS}

Field sampling. Field sampling of marine snow took place in the waters of the Atlantic and the Pacific Oceans. Samples were collected on 3 dates between August and November of 1991 in the Atlantic Ocean approximately $3 \mathrm{~km}$ offshore of Charleston, South Carolina, USA $\left(31^{\circ} 43^{\prime} \mathrm{N}, 78^{\circ} 43^{\prime} \mathrm{W}\right)$. In the Pacific Ocean samples were collected on 5 dates between July and August 1992 in Parks Bay, Shaw Island (48 33' $\mathrm{N}$, $\left.122^{\circ} 59^{\prime} \mathrm{W}\right)$, and on 2 dates in August 1992 in West Sound, Orcas Island $\left(48^{\circ} 37^{\prime} \mathrm{N}, 122^{\circ} 58^{\prime} \mathrm{W}\right)$. Shaw and Orcas Islands are located in the San Juan Islands, Washington, USA.

From 4 to 6 replicate marine snow samples containing 30 to 200 aggregates $>1 \mathrm{~mm}$ in longest dimension were collected from between 3 and $5 \mathrm{~m}$ depth by SCUBA divers using the technique of shanks $\tilde{\alpha}$ Edmondson (1990). Aggregates were drawn into a $1 \mathrm{ml}$ sampling syringe and transferred via a connected $\mathrm{T}$-valve into a $50 \mathrm{ml}$ reservoir syringe. With this sampling technique 100 aggregates can be concentrated in $<25 \mathrm{ml}$ of water. In the collection procedure, the sampling syringe was mounted on a frame with an underwater flashlight to aid visualization of the aggregates. The beam from the flashlight illuminated the water in front of the intake for the sample syringe. Due to the light reflected off of the aggregates, even the clear mucus matrix of the marine snow was visible. The diver swam to the up-current end of their tether and sampled as the current carried them to the downstream end of their tether. Sampling was haphazard; the diver sampled aggregates in sequence as they passed through the beam of the flashlight.

On 20 August 1992 in West Sound it appeared to the divers that there were 2 size classes of aggregates. Small aggregates tended to be between 1 and $5 \mathrm{~cm}$ in longest dimension and large aggregates were $>10 \mathrm{~cm}$ in longest dimension (see Table 2). Divers collected separate replicate samples of 'small' (100 aggregates sample $\left.{ }^{-1}\right)$ and 'large' (30 aggregates sample ${ }^{-1}$ ) aggregates.

Plankton samples (i.e. marine snow and the water surrounding marine snow) were collected in the Atlantic Ocean samples using a submersible bilge pump. Water (37.5 l) was pumped from the depth at which the marine snow was sampled and filtered through a $53 \mu \mathrm{m}$ mesh plankton net. In the Pacific Ocean plankton samples were collected with a $25 \mathrm{~cm}$ diameter $53 \mu \mathrm{m}$ mesh plankton net. The net was towed vertically from $6 \mathrm{~m}$ to the surface (approximately $300 \mathrm{l}$ 
filtered). All samples were stained with Rose Bengal and preserved in $3 \%$ Formalin.

The size and concentration of marine snow was determined using the photographic technique developed by Honjo et al. (1984). About 30 photographs of a $13.2 \times 9.2 \times 5 \mathrm{~cm}$ volume of water $(0.607$ l) were taken at depths between 3 and $5 \mathrm{~m}$. Photographs were taken at random using the following procedure. Divers adjusted their buoyancy to become neutrally buoyant, closed their eyes, drifted with the current for $15 \mathrm{~s}$ (the time needed to recharge the strobes), and then took a photograph. The process was repeated until the entire role of film had been exposed. Photographs were projected (11.5 $\times$ the image size) onto a digitizing pad and the dimensions of all aggregates greater than $1 \mathrm{~mm}$ (the size of the smallest aggregates collected by divers) were determined. The volume of ellipsoidal aggregates was calculated from the diameter assuming a spherical shape. The volume of long aggregates was calculated from long and short axes measurements assuming a cylindrical shape. In each photograph the number of aggregates $>1 \mathrm{~mm}$ in any dimension was determined and used to calculate the concentration of aggregates (i.e. number $\mathrm{l}^{-1}$ )

Polychaetes in marine snow and plankton samples were enumerated at $400 \times$ under white light using a compound microscope. Except for the large marine snow samples collected on 20 August the entire aggregate sample was enumerated. The large aggregate samples from 20 August and the plankton samples were aliquoted prior to microscopic examination using a Stempel pipette (Omori \& Ikeda 1984). Samples or aliquots from samples were placed in $15 \mathrm{ml}$ centrifuge tubes and spun for 5 min on a hand-crank centrifuge. Sedimented animals were removed from the tube with a Pasteur pipette and placed in a Sedgwick Rafter cell.

Polychaete larvae from 11 of the 12 families enumerated were classified as precompetent or competent depending on the number of setigers present. Because larvae in the family Arenicolidae were in tubes, it was impossible to count the number of setigers, hence, the relative competency of these arvae was not determined. Larvae belonging to the family Eunicidae were considered competent regardless of setiger number since these larvae are not considered to have a planktonic stage from which they must settle to the benthos (Thorson 1946). The number of setigers present at competency for each family was based on the literature and where a range of values were found for the number of setigers present at competency, an intermediate number was chosen (see Table 1)

Laboratory experiments. Four species of polychaetes were collected for laboratory experiments: Nereis succinea, Arenicola cristata, Autolytus sp., and Serpula vermicularis. $N$. succinea and $A$. cristata were
Table 1 Estimated minimum number of setigers present at competency in larvae from 10 of the 12 polychaete families sampled during this study

\begin{tabular}{|lcl|}
\hline Family & $\begin{array}{c}\text { Setigers at } \\
\text { competency }\end{array}$ & Source \\
\hline Glyceridae & 10 & Thorson (1946) \\
Magelonidae & 27 & Thorson (1946) \\
Nephtyidae & 9 & Rasmussen (1973) \\
Nereldae & 4 & Strathmann (1987) \\
Onuphidae & 6 & Bhaud \& Cazaux (1987) \\
Phyllodocidae & 15 & Strathmann (1987) \\
Sabellaridae & 7 & Bhaud \& Cazaux (1987) \\
Serpulidae & 5 & Strathmann (1987) \\
Spionidae & 16 & Rasmussen (1973) \\
Terebellidae & 5 & Thorson (1946) \\
\end{tabular}

collected in Charleston, South Carolina. Ripe N. succinea adults were collected during 2 epitokous swarming events which took place on 12 and 24 April 1993 in the boat slip at the South Carolina Marine Resources Research Institute, Charleston, South Carolina $\left(31^{\circ} 43^{\prime} \mathrm{N}, 78^{\circ} 43^{\prime} \mathrm{W}\right)$. A cristata egg masses were collected at Bull Island, South Carolina $\left(33^{\circ} 5^{\prime} \mathrm{N}\right.$, $\left.79^{\circ} 27^{\prime} \mathrm{W}\right)$ on 16 May 1992. Brooding Autolytus sp. were collected between 16 July and 12 August 1992 at night from the Friday Harbor Laboratories (University of Washington, Friday Harbor, Washington, USA) dock. Ripe $S$. vermicularis adults were collected from Argyle Creek, San Juan Island, Washington during August 1992 and May 1993.

Standard techniques (Strathmann 1987) were used to spawn Nereis succinea and Serpula vermicularis and maintain their larvae in the laboratory. $N$. succinea larvae were used in laboratory experiments at $48 \mathrm{~h}$ ( 3 setigerous body segments) and $96 \mathrm{~h}$ (>3 setigerous body segments) after fertilization. $S$. vermicularis larvae were used in laboratory experiments approximately 16 and $30 \mathrm{~d}$ after fertilization. The gelatinous egg masses of Arenicola cristata were held in the laboratory at $24^{\circ} \mathrm{C}$ in aerated plastic tubs filled with $1 \mu \mathrm{m}$ filtered seawater. The non-feeding larvae were used in laboratory experiments within $24 \mathrm{~h}$ after hatching from the egg masses (4 setigers) Brooding Autolytus sp. adults were maintained in running seawater tables and their non-feeding, crawl-away larvae were used in experiments within $24 \mathrm{~h}$ after emerging from the brood sac.

Artificial marine snow was made in the laboratory using the roller table technique of Shanks \& Edmondson (1990). Unfiltered seawater was added to $11(14 \mathrm{~cm}$ diam $\times 6.5 \mathrm{~cm}$ deep) cylindrical Plexiglas tanks. These tanks were rotated on the roller table at approximately $15 \mathrm{rpm}$. Aggregates formed within $1.5 \mathrm{~h}$. All experiments were run at the same temperature at which the larvae had been raised. 
Initial experiments using Arenicola cristata and Autolytus sp. larvae indicated that there was not a significant difference in the degree of association of these larvae with aggregates if they were added to the tanks before or after the formation of aggregates. The remaining laboratory experiments were all conducted by adding the larvae to the roller table tanks prior to the formation of aggregates. An average of 40 larvae were added to each tank. The tanks were placed on the roller table and rotated for 8 to $12 \mathrm{~h}$

At the end of each experiment, black and white photographs were taken through the face of each of the still-rotating tanks. The photograph was captured to a video monitor and using an image analysis program. the number and diameter of marine snow in each tank was then determined. The volume of aggregates was calculated assuming they were spheres.

Immediately following the photography, each tank was sampled while still rotating on the roller table. As many macroscopic aggregates as possible were removed from each tank with a syringe. The syringe needle was inserted through the serum cap tank stopper. The organisms remaining in the tank after the removal of the marine snow were captured by filtering the water through a $25 \mu \mathrm{m}$ mesh sieve. The laboratory plankton samples were stained with Rose Bengal and preserved in $3 \%$ Formalin. The number and identity of the organisms in these samples were determined using the techniques outlined above for the processing of the field samples.

Behavioral observations. Observations of the response of polychaete larvae to marine snow were made in a vertical flume which was designed to suspend marine snow so that observations could be made through a dissecting microscope. The vertical flume consisted of a Plexiglas tank $7 \times 15 \times 5 \mathrm{~cm}$. Water entered the tank from the bottom and passed through a baffle before entering the working section of the flume. Water exited at the top of the tank through a ring of tiny holes. An adjustable peristaltic pump was used to circulate the water through the tank. A surge damper was placed between the pump and the tank intake that removed most of the surging motion of the flow generated by the peristaltic pump.

Observations were made with a dissecting microscope mounted horizontally in front of the tank. The flume was mounted on a scissors jack which allowed the adjustment of the vertical position of objects in the tank relative to the microscope. The horizontal positioning and focusing of the microscope was achieved by mounting the microscape on a pair of linear motion ball bearing slides. The linear motion slides were mounted perpendicular to each other thus allowing smooth horizontal motion and focusing of the microscope. Lighting was provided by a fiber optic lamp with a red filter over the output lens. With this system an aggregate and associated organisms could be observed for many minutes through the dissecting microscope.

Polychaete larvae collected from the field with a $53 \mu \mathrm{m}$ plankton net were placed in the vertical flume along with aggregates made in the laboratory on the roller table. Aggregates were no more than $24 \mathrm{~h}$ old and were transferred from the roller table tanks to the vertical flume with a wide bore $(1 \mathrm{~cm})$ pipette. An aggregate was selected from those present in the middle of the vertical flume and this aggregate was observed for as long as possible. Aggregates would eventually migrate sideways across the tank until they entered the boundary layer next to one of the side walls at which point they would sink to the bottom of the tank in the reduced flow field of the boundary layer. While an aggregate was under observation all of the responses of organisms upon contacting an aggregate were noted. Approximately $12 \mathrm{~h}$ of observations were made during this study.

\section{RESULTS}

\section{Field sampling}

Marine snow was present and abundant on every dive. Aggregates were most numerous though small in the Atlantic samples collected off Charleston, South Carolina (Table 2). Aggregate volume varied over a wide range. The smallest aggregates (4 October 1991, Table 2) were only $0.0004 \mathrm{ml}$ in volume, while the largest had an average volume of almost $36 \mathrm{ml}$ (20 August 1992 large, Table 2); aggregate volume spanned 5 orders of magnitude. Although aggregates were present and abundant everywhere they made up only a tiny portion of the water column (Table 2). At most they made up only $0.5 \%$ of the water by volume (small plus large aggregates on 20 August 1992, Table 2).

Larval polychaetes were caught in marine snow samples on all dives (Table 3). If larval polychaetes are significantly associated with aggregates then the concentration of larvae in the aggregate samples must be significantly higher than the concentration of larvae in the plankton tow samples. On 4 October 1991 in the Atlantic and 28 July 1992 and 31 July 1992 in the Pacific, the concentration of larvae in the aggregate samples was not significantly different from that in the plankton tows (Mann-Whitney $U$-test, $p>0.05$ ); larvae were not clearly associated with aggregates on these dates. On all other dates there were significantly higher concentrations of larvae in aggregates than in the plankton samples (Mann-Whitney $U$-test, $p>0.05$ ); larval polychaetes were strongly associated with aggregates. 
Although larval polychaetes were usually significantly more concentrated in aggregates, they were generally rare components of the community of organisms on aggregates. Excluding the large aggregates sampled on 20 August 1992, there was on average only about 5 polychaete larvae per 100 aggregates or only 0.05 larvae aggregate-1 (Table 3 ). Larval polychaetes were much more abundant on aggregates in West Sound. Here in the small aggregates sampled on 20 August 1992 and the aggregates sampled on 27 August 1992 we found 17.75 and 8.83 polychaete larvae per 100 aggregates respectively (Table 3 ). In the large aggregates sampled on 20 August 1992 there were 3.3 larvae in each aggregate (Table 3).

Knowing the number of larvae aggregate ${ }^{-1}$ (Table 3) and the number of aggregates $1^{-1}$ (Table 2) we calculated the number of larvae $\mathrm{m}^{-3}$ which were on aggregates (Table 3). To determine the concentration of larvae in the water surrounding the aggregates we subtracted the concentration of larvae on aggregates from the total concentration of larvae as determined from the plankton tows or pump samples. Lastly, using

Table 2. Physical characteristics of marine snow sampled in the Atlantic and Pacific Oceans. Values are means and SDs are given in parentheses

\begin{tabular}{|c|c|c|c|c|c|}
\hline Date & Length (mm) & Diameter (mm) & Volume (ml) & No. $l^{-1}$ & $\%$ Conc of agg by vol. \\
\hline \multicolumn{6}{|l|}{ Atlantic, Charleston } \\
\hline 30 Aug 1991 & $2.01(2.38)$ & $0.58(0.55)$ & $0.0013(0.0058)$ & $62.82(48.29)$ & 0.008 \\
\hline 4 Oct 1991 & $1.68(1.34)$ & $0.50(0.28)$ & $0.0004(0.004)$ & $13.48(9.98)$ & 0.006 \\
\hline 1 Nov 1991 & $1.55(1.47)$ & $0.60(0.33)$ & $0.0007(0.0018)$ & $53.13(19.66)$ & 0.004 \\
\hline \multicolumn{6}{|l|}{ Pacific, Parks Bay } \\
\hline 22 Jul 1992 & $5.18(8.79)$ & $0.72(0.77)$ & $0.0181(0.613)$ & $4.70(1.81)$ & 0.009 \\
\hline $28 \mathrm{Jul} 1992$ & $2.26(1.98)$ & $0.44(0.17)$ & $0.0005(0.0009)$ & $8.71(4.01)$ & 0.0004 \\
\hline $31 \mathrm{Jul} 1992$ & $1.43(0.92)$ & $0.82(0.22\}$ & $0.0009(0.0009)$ & $11.04(4.66)$ & 0.001 \\
\hline 3 Aug 1992 & $3.81(5.84)$ & $1.22(0.84)$ & $0.0120(0.0265)$ & $3.29(2.55)$ & 0.004 \\
\hline 6 Aug 1992 & $6.15(10.78)$ & $0.96(0.56)$ & $0.0112(0.382)$ & $3.29(2.77)$ & 0.004 \\
\hline \multicolumn{6}{|l|}{ Pacific, West Sound } \\
\hline 20 Aug 1992 , small & $55.46(68.28)$ & $5.27(6.57)$ & $1.295(3.772)$ & $1.01(1.08)$ & 0.131 \\
\hline 20 Aug 1992, large & $156.75(20.15)$ & $17.10(0.00)$ & $35.981(4.626)$ & $0.11(0.44)$ & 0.396 \\
\hline 27 Aug 1992 & $51.60(58.37)$ & $3.22(2.94)$ & $1.135(4.084)$ & $2.14(1.68)$ & 0.243 \\
\hline Average over all dates & & & & & $0.08(0.16, \Omega=10)$ \\
\hline
\end{tabular}

Table 3 . Overall abundance of larval polychaetes on marine snow aggregates, numbers of larvae $\mathrm{m}^{-3}$ residing on aggregates and in the aggregate-free surrounding waters, and the percent of the polychaete larvae which were associated with aggregates. Values are means with SDs and number of replicates in parentheses. nc: the concentration of larvae in the aggregate samples was not significantly different from the concentration in the plankton samples; no further calculations were made. Calculations of overall average were made assuming the percentages of larvae in aggregates on 4 Oct 1991, 28 Oct 1992, and 31 Jul 1992 were 0 and summing the percentage for small and large aggregates for 20 Aug 1992

\begin{tabular}{|c|c|c|c|c|}
\hline Date & No. per 100 agg. & No. $m^{-3}$ in agg. & No. $\mathrm{m}^{-3}$ in surr. water & $\%$ of total in agg \\
\hline \multicolumn{5}{|l|}{ Atlantic, Charleston } \\
\hline 30 Aug 1991 & $1.88(1.09,4)$ & $1179(683,4)$ & $5542(1486,5)$ & 18 \\
\hline 4 Oct 1991 & $1.56(0.52,4)$ & $\mathrm{nc}$ & $591(113,5)$ & nc \\
\hline 1 Nov 1991 & $2.63(1.07,8)$ & $1393(581,8)$ & $601(433,5)$ & 70 \\
\hline \multicolumn{5}{|l|}{ Pacific, Parks Bay } \\
\hline 22 Jul 1992 & $2.00(0.66,7)$ & $94(31,7)$ & $3207(613,5)$ & 3 \\
\hline $28 \mathrm{Jul} 1992$ & $0.30(0.27,5)$ & nc & $2881(490,5)$ & nc \\
\hline 31 Jul 1992 & $0.13(0.13,4)$ & $\mathrm{nC}$ & $633(213,5)$ & nc \\
\hline 3 Aug 1992 & $2.75(0.91,4)$ & $54(4,4)$ & $928(289,5)$ & 6 \\
\hline 6 Aug 1992 & $2.2(1.15,5)$ & $44(23,5)$ & $535(103,5)$ & 8 \\
\hline \multicolumn{5}{|l|}{ Pacific, West Sound } \\
\hline 20 Aug 1992, small & $17.75(2.56,4)$ & $116(19,4)$ & $1947(500,5)$ & 27 \\
\hline 20 Aug 1992, large & $330(77,4)$ & $870(204,4)$ & $1947(500,5)$ & 4 \\
\hline 27 Aug 1992 & $8.83(2.51,6)$ & $109(31,6)$ & $300(55,5)$ & 27 \\
\hline Average over all dates & & & & $16(22,10)$ \\
\hline
\end{tabular}


these values we determined the percentage of the larvae in the water column which were on aggregates (Table 3). Note that these calculations were not applied to the data from 4 October 1991, 28 July 1992 or 31 July 1992 when there were not significantly higher concentrations of larvae in the aggregate samples (as described above)

The total number of larval worms ranged from a low of only $409 \mathrm{~m}^{-3}$ on 27 August 1992 (no. $\mathrm{m}^{-3}$ in agg. plus no. $\mathrm{m}^{-3}$ in surr., Table 3) to a high of $6721 \mathrm{~m}^{-3}$ on 30 August 1991. Larval polychaetes in aggregates ranged from only $16 \mathrm{~m}^{-3}$ on 28 July 1992 to a high of $1179 \mathrm{~m}^{-3}$ on 30 August 1991. The lowest concentra-

Table 4. Percentage of precompetent and competent larval polychaetes in the plankton samples and associated with aggregates on those days when there was a significant difference between the concentration of larvae on the aggregate and plankton samples. For 20 Aug 1991 the results from the small and large aggregates have been combined

\begin{tabular}{|lcccc|}
\hline Date & $\begin{array}{c}\text { Percentage in } \\
\text { planiniun } \\
\text { Precomp. }\end{array}$ & \multicolumn{2}{c|}{$\begin{array}{c}\text { Percentage of larvae } \\
\text { dssociated with agg. } \\
\text { Precomp. }\end{array}$} \\
\hline 30 Aug 1991 & 90 & 10 & 12 & 88 \\
1 Nov 1991 & 90 & 10 & 24 & 76 \\
22 Jul 1992 & 84 & 16 & 16 & 84 \\
3 Aug 1992 & 93 & 7 & 7 & 93 \\
6 Aug 1992 & 96 & 4 & 5 & 95 \\
20 Aug 1992 & 74 & 26 & 37 & 69 \\
27 Aug 1992 & 58 & 42 & 42 & 58 \\
Mean \pm SD & $84 \pm 13$ & $16 \pm 13$ & $20 \pm 15$ & $80 \pm 14$ \\
& & & &
\end{tabular}

Table 5. Percentage of precompetent and competent larvae from the 12 polychaete families observed during the study which were associated with aggregates. Values are means. In parentheses for each mean is the SD (-: not calculated because $n=1$ ) and the ratio of the number of days when aggregates contained this family and stage to the total number of days when this family and stage were observed in the plankton pump or net samples

\begin{tabular}{|lcc|}
\hline Family & $\begin{array}{c}\text { Percentage of larvae on aggregates } \\
\text { Precompetent }\end{array}$ & $100(-, 1 / 1)$ \\
Competent & \\
Arenicolidae & - & $49(17,5 / 8)$ \\
Gunicidae & - & $67(33,2 / 3)$ \\
Magelidae & $33(3,1 / 3)$ & - \\
Nephtyidae & $0(-, 0 / 1)$ & $100(0,3 / 3)$ \\
Nereidae & $100(0,5 / 5)$ & $40(24,2 / 5)$ \\
Onuphidae & $13(12,2 / 8)$ & $44(20,4 / 7)$ \\
Phyllodocidae & $16(12,4 / 8)$ & $67(21,4 / 6)$ \\
Sabellaridae & $17(12,5 / 8)$ & $50(29,2 / 4)$ \\
Serpulidae & $23(12,5 / 8)$ & $0(0,0 / 2)$ \\
Spionidae & $0(0,0 / 2)$ & $23(15,3 / 7)$ \\
Terebellidae & $16(12,7 / 8)$ & $50(-, 1 / 1)$ \\
\hline
\end{tabular}

tions of larvae associated with aggregates were found in Parks Bay and the highest in the Atlantic samples (Table 3).

A better gauge of the degree of association of larvae polychaetes with aggregates is provided by the percentage of the larval polychaete population found on aggregates (Table 3 ). The percent of the larval polychaetes on aggregates ranged from around 0 (4 October 1991, 28 July 1992 and 31 July 1992) to a high of $70 \%$ on 1 November 1991 . Overall $16 \%$ of the larval polychaetes were caught on aggregates (Table 3 ).

The lowest percentages were found in the samples from Parks Bay and the highest in the samples collected from the Atlantic and West Sound (Table 3). There was no relationship between the percentage of larval polychaetes associated with aggregates and the size of the aggregates, concentration of aggregates, or the percentage of the water volume made up of aggregates (Tables $2 \& 3$ ). The variation in the degree of association of larval polychaetes with aggregates was apparently due to some unmeasured variation in the quality of aggregates.

Comparing the percontage of the water column made up of aggregates (on average $0.08 \%$, Table 2 ) to the percentage of the polychaetes in aggregates (on average $16 \%$, Table 3 ) it is obvious that larval polychaetes were highly concentrated in marine snow. These values suggest that larval polychaetes were on the order of 200 times more concentrated on aggregates than in an equal volume of the aggregate-free surrounding water.

We compared the percentage of precompetent and competent larvae in the plankton samples to the percentage of larvae in the water column which were associated with aggregates (Table 4). Precompetent larvae made up an average of $84 \%$ ( $\mathrm{SD}=13 \%$ ) of the larval polychaetes in the plankton sample. On average $20 \%(\mathrm{SD}=15 \%)$ of these precompetent larval polychaetes were on aggregates (Table 4). The distribution of competent larval polychaetes was quite different. On average competent larval polychaetes made up only $16 \%(\mathrm{SD}=13 \%)$ of the larval polychaetes in the plankton, but, of these individuals, $80 \%(\mathrm{SD}=14 \%)$ were residing on aggregates.

Twelve families of polychaetes were present in plankton samples of which 10 were found in the aggregates samples (Table 5). The 2 families which were not found in aggregates, Magelonidae and Serpulidae, were only present in the plankton samples on 1 and $2 \mathrm{~d}$ respectively. All of the Nephtyidae, precompetent and competent larvae, were associated with aggregates. In general, across the 10 polychaete families found on aggregates, there was a lower percentage of the precompetent larvae than competent larvae associated with marine snow (Table 5). 
Table 6. Results of laboratory experiments: aggregate physical characteristics (size, volume, and no. aggregates $1^{-1}$ ) and degree of association of larvae with aggregates (no. of larvae per 100 aggregates and \% of larvae on aggregates). Values are means with the SD and number of replicates in parentheses. nc: concentration of larvae in the aggregate samples was not significantly different from the concentration in the plankton samples; no further calculations were made

\begin{tabular}{|c|c|c|c|c|c|}
\hline Date & Agg. diameter $(\mathrm{mm})$ & Agg. vol. $(\mathrm{ml})$ & No. agg. $1^{-1}$ & No. per $100 \mathrm{agg}$. & $\%$ of larvae on agg. \\
\hline \multicolumn{6}{|c|}{ Arenicolidae, Arenicola cristata } \\
\hline 18 May 1992 & $4.4(0.4,12)$ & $0.0004(0.0001,12)$ & $121(26,12)$ & $21(10,12)$ & $39(16,12)$ \\
\hline \multicolumn{6}{|l|}{ Syllidae, Autolytus sp. } \\
\hline 23 Jul 1992 & $4.7(0.4,8)$ & $0.0004(0.0001,8)$ & $11(3,8)$ & $16(14,8)$ & $\mathrm{nc}$ \\
\hline 29 Jul 1992 & $4.7(0.3,6)$ & $0.0004\{0.0000,6\}$ & $19(4.0,6)$ & $65(30,6)$ & $15(10,6)$ \\
\hline 5 Aug 1992 & $4.4\{0.3,6\}$ & $0.0004(0.0001,6)$ & $22(8.4,6)$ & $58(41,6)$ & $10(4,6)$ \\
\hline 13 Aug 1992 & $4.7(0.5,6)$ & $0.0005(0.0001,6)$ & $17(5.0,6)$ & $15(9,6)$ & $6(3,6)$ \\
\hline \multicolumn{6}{|c|}{ Serpulidae, Serpulia vermicularis } \\
\hline 27 Aug 1992,16 d old & $4.7(0.5,6)$ & $0.0004(0.0001,6)$ & $17(3.3,6\}$ & $1(3,6)$ & nc \\
\hline 18 Aug $1993,30 \mathrm{~d}$ old & $4.3(0.6,6)$ & $0.0040(0.0010,6)$ & $37(9.4,6)$ & $75(16,6)$ & $83(16,6)$ \\
\hline \multicolumn{6}{|c|}{ Nereidae, Nereis succinea } \\
\hline 13 Apr 1993,2 d old & $3.9(0.3,6)$ & $0.0003(0.0001,6)$ & $76(31.0,6)$ & $4(5,6)$ & $11(4,6)$ \\
\hline 14 Apr 1993, 2 d old & $4.4(0.4,6)$ & $0.0004(0.0001,6)$ & $40(11.0,6)$ & $12(9,6)$ & $31(23,6)$ \\
\hline $28 \mathrm{Apr} 1993,4 \mathrm{~d}$ old & $4.5(0.6,6)$ & $0.0004(0.0001,6)$ & $64(17.0,6)$ & $8(4,6)$ & $19(5,6)$ \\
\hline $29 \mathrm{Apr} 1993,4 \mathrm{~d}$ old & $4.6(0.2,6)$ & $0.0004(0.0001,6)$ & $54(21.0,6)$ & $3(3,6)$ & $6(5,6)$ \\
\hline
\end{tabular}

\section{Laboratory experiments}

In laboratory experiments (Table 6), 21 Arenicola cristata larvae were found per 100 laboratory-made aggregates. On average $39 \%$ of the $A$. cristata larvae in the tanks were associated with aggregates. Four laboratory experiments using Autolytus sp. larvae were carried out in 1992 (Table 6). In 3 of the 4 experiments Autolytus sp. were significantly concentrated in the aggregate samples (Mann-Whitney $U$-test, p < 0.05 ) and between 6 and $15 \%$ of the larvae were in aggregates. In the laboratory, experiments were performed using precompetent ( $16 \mathrm{~d}$ old) and competent (30 d old) larvae of Serpulia vermicularis (Table 6). Precompetent $S$. vermicularis larvae were not significantly concentrated on aggregates (Mann-Whitney $U$ test, $\mathrm{p}<0.05$ ) while the competent larvae were (MannWhitney $U$-test, $\mathrm{p}<0.05$ ) and, in the later case, $83 \%$ of the larvae were associated with aggregates. In the laboratory both 2 and 4 d old larvae of Nereis succinea were significantly concentrated (Mann-Whitney $U$ test, $\mathrm{p}<0.05$ ) on aggregates (Table 6 ). The percentage of $N$. succinea on aggregates ranged from 6 to $31 \%$ with no significant difference in the degree of association with aggregates between the different aged larvae $(1-$ way ANOVA, $p<0.05)$.

\section{Behavior observations}

Using the vertical flume approximately $12 \mathrm{~h}$ of observations were made on the behavior of polychaete larvae upon contacting marine snow. A total of 11 in- teractions were observed ( 8 spionids, 1 sabellarid and 2 nereids). In each case the response was similar. Upon contacting the aggregate, the larvae stopped swimming and began crawling over the external surface of the aggregate or entered and crawled about inside. This is in marked contrast to the behavior of other plankters upon contacting aggregates. For example, adult calanoid copepods upon contacting aggregates simply bumped the aggregate and then jumped away (authors' pers. obs.). The polychaete larvae remained on the aggregate for on average $2 \pm 1.5$ min after which they left the aggregate and swam off into the surrounding water or the aggregate was lost to view. All but 1 of the observations was made on precompetent larvae. The behavior of the 1 competent spionid observed was not obviously different from that of the precompetent larvae. It remained on the aggregate for 5 min before the aggregate was lost from view. Larvae did not obviously change course to approach aggregates, rather larvae which visited aggregates appeared to simply bump into them; at least in the vertical flume, larval polychaetes were not obviously attracted to aggregates. The conclusions to be drawn from these observations are: (1) larvae were not passively entangled in aggregates, rather the association was due to the activity of the larvae; and (2) larvae appeared to visit aggregates; remaining for several minutes and then swimming away.

\section{DISCUSSION}

Marine snow was present on all 10 sample dates and on 8 of those dates larval polychaetes were signifi- 
cantly concentrated in aggregates. Despite the fact that aggregates accounted for only a tiny portion of the water column by volume (on average only $0.08 \%$, Table 2) $16 \%$ of all larval polychaetes in the water column were associated with aggregates. Larval polychaetes were highly concentrated on aggregates. If the larval polychaetes are separated into precompetent and competent stages the association with marine snow becomes even more striking. Precompetent larval polychaetes made up an average of $84 \%$ of the polychaete larvae in the water column and of these larvae $20 \%$ were associated with aggregates (Table 4 ). In contrast, competent larval polychaetes made up only $16 \%$ of the polychaete larvae, but $80 \%$ of them were on aggregates. Larval polychaetes were not randomly distributed in the water column. They tended to be highly concentrated in a tiny volume of the water column, the marine snow.

We limited the ficld sampling to aggregates larger than $1 \mathrm{~mm}$ in diameter. At all study sites numerous aggregates smaller than $1 \mathrm{~mm}$ were present. During the observations of larvae in the vertical flume we saw larval polychaetes associate with aggregates smaller than $1 \mathrm{~mm}$. It is quite likely that polychaete larvae associate with aggregates $<1 \mathrm{~mm}$ in diameter in the field. If this is indeed the case then we have underestimated the actual degree of association of larval polychaetes with aggregates.

Polychaete larvae, especially competent larval stages were strongly associated with marine snow. This conclusion is similar to that found in 3 previous studies (Shanks \& Edmondson 1990, Bochdansky \& Herndl 1992, Green \& Dagg 1997). Shanks \& Edmondson (1990) found that on average 9 and $74 \%$ of the precompetent and competent larval polychaetes respectively were concentrated on aggregates. Bochdansky \& Herndl (1992) found that in the northern Adriatic Sea larval polychaetes, especially spionid nectochaetes, were strongly associated with aggregates. Green \& Dagg (1997) found from 7 to $36 \%$ of the larval polychaetes (all stages) were on aggregates collected in the Gulf of Mexico. To date, the association of larval polychaetes with marine snow has been investigated at 2 locations in the Atlantic Ocean along the east coast of North America, at 2 coastal sites in the Eastern North Pacific, at a coastal site in the northern Adriatic Sea, and in the northern Gulf of Mexico (Shanks \& Edmondson 1990, Bochdansky \& Herndl 1992, Green \& Dagg 1997, this study). Given the similarity of the conclusions drawn by these studies and the broad geographic range of the study sites it seems safe to conclude that in temperate coastal waters larval polychaetes, particularly competent larvae or nectochaetes, are strongly associated with aggregates.
Sampling in the 3 previous studies (Shanks \& Edmondson 1990, Bochdansky \& Herndl 1992, Green \& Dagg 1997) was not as extensive as that carried out for this study. Hence, the lists of polychaete families encountered on aggregates in these previous studies are not as extensive as that reported here (Table 5). Shanks \& Edmondson (1990) and Bochdansky \& Herndl (1992) found larvae from the families (1) Magelonidae, Spionidae, and Nephtyidae and (2) Spionidae, Nereidae, and Disomidae respectively on aggregates. Green \& Dagg (1997) did not identify larval polychaetes to family. In the field samples, we found 10 families associated with aggregates (Table 5) including Spionidae, Nephtyidae, and Nereidae which had previously been observed on aggregates. We did not find larvae from the family Disomidae in any of the plankton samples, and Magelonidae was only present on 1 sample date, at very low numbers, and their larvae were not found in aggregates. In addition, the laboratory experiments suggest that larvae from the families Syllidae and Serpulidae may also at times be associated with aggregates. These results indicate that a wide diversity of polychdetes associate with aggregates and that some families at least (e.g. Spionidae, Nephtyidae, and Nereidae) are regular components of the metazoan community on aggregates.

The observations in the vertical flume indicate that the association of larval polychaetes is an active one. They do not simply become entangled with marine snow and then are unable to leave. Rather, larvae swimming free in the water, upon contacting an aggregate, stopped swimming and began to glide over the surface or through the interior of the aggregate. After several minutes of crawling about an aggregate larvae were observed to break contact and swim off into the surrounding water. From these observations we can conclude that the association of larval polychaetes with aggregates is active and, tentatively, that larvae may not reside on aggregates for long periods, but rather they visit aggregates for several minutes at a time.

On average 20 and $80 \%$ of the precompetent and competent larval polychaetes respectively were on aggregates (Table 4). If we assume that larval polychaetes visit rather than reside on aggregates then these percentages can be used to estimate the average amount of time the larvae spend on aggregates. These estimations suggest that precompetent and competent larval polychaetes spend around 5 and $19 \mathrm{~h} \mathrm{~d}^{-1}$ respectively on aggregates. The observations in the vertical flume suggest that each visit might be around 2 min long. Assuming that each visit is of this duration then precompetent and competent larvae are able to visit about 140 and 580 aggregates $d^{-1}$ respectively. These are, obviously, very crude estimates, but they do give a rough idea of the amount of contact polychaete larvae 
might have with marine snow. The large amount of time larvae may be spending on aggregates and the number of aggregates they may visit during a day give some idea of the role marine snow might be playing in the lives of larval polychaetes.

Why might larval polychaetes visit marine snow? The most likely explanation is that they are feeding on the concentration of detritus and microbes which are characteristic components of marine snow (Alldredge \& Silver 1988). Microbial populations on aggregates are generally at least 10 times more concentrated in aggregates than in the surrounding water and at times they are 1000 times more concentrated (Silver et al. 1978, Caron et al. 1983, Alldredge \& Youngbluth 1985, Beers et al. 1986, Davoll \& Silver 1986, Alldredge \& Silver 1988). The high concentrations of microbes in aggregates has suggested to a number of investigators that aggregates may be a food resource exploited by marine organisms. Several studies have provided evidence suggesting that this may be the case (Alldredge 1976, Silver et al. 1978, Lampitt 1985, Suh et al. 1991, Larson \& Shanks 1996).

Bochdansky \& Herndl (1992) during the microscopic examination of unpreserved marine snow samples observed spionid polychaete larvae feeding on the particulate matrix of marine snow. Preliminary experiments in our laboratory also suggest that polychaete larvae are feeding on the particulate matrix of aggregates (A.L.S. unpubl. data). Using the techniques of Larson \& Shanks (1996) we incorporated $1 \mu \mathrm{m}$ fluorescent beads into marine snow. Using this technique more than $90 \%$ of the beads become bound to marine snow. All of the polychaete larvae exposed for several hours in roller tanks to laboratory-made marine snow which had been 'tagged' with fluorescent beads contained fluorescent beads and produced fecal pellets packed with beads. In contrast, larvae maintained under the same conditions except that a rotating magnetic stir bar in the roller tank prevented the formation of aggregates contained few beads in either their guts or fecal pellets. These observations suggest that polychaete larvae visiting aggregates feed on the aggregate-bound detritus and microbes

The available evidence on feeding of polychaete larvae on aggregates coupled with the observed strong association with aggregates suggests that feeding on marine snow may be an important component of the diet of larval polychaetes. Does variation in the abundance of marine snow or the composition and concentration of the microbial population on aggregates affect the nutrition and survival of polychaete larvae? For example, the aggregates sampled in Parks Bay were small and during microscopic examination appeared to contain few protozoans; larval polychaetes were more weakly associated with these aggregates than at the other sample sites (Table 3). In contrast, the aggregates sampled in West Sound were quite large and contained numerous protozoans (Shanks \& Walters 1996): larval polychaetes were more strongly associated with these aggregates. Perhaps the low abundance of microbes on the Park Bay marine snow made these aggregates less appealing than the aggregates sampled in West Sound

While larval polychaetes are residing on aggregates they will move with the aggregate (Shanks \& Edmondson 1990). Most studies have found that marine snow sinks (Asper 1986, Alldredge \& Gotschalk 1988, Riebesell 1989, Shanks \& Edmondson 1990) and that much of the vertical flux of material through the water column can be due to marine snow (Shanks \& Trent 1980, Asper 1986, Riebesell 1989, Walsh \& Gardner 1992, Syvitski et al. 1995, Lampitt 1996). A few studies, however, have also found, due to gas production by microbes on aggregates, that at times aggregates can be positively buoyant (Riebesell 1989, Herndl 1992) Shanks \& Edmondson (1990) found that most of the vertical flux through the water column of competent larval polychaetes was due to larvae associated with aggregates. Competent larval polychaetes appear to spend a large percentage of the day on aggregates. Larvae on sinking aggregates will be passively transported toward the bottom and may eventually be deposited on the bottom if the aggregate in which they are residing hits the bottom. To the extent that this scenario is true, larval polychaetes will sink through the water column as passive particles (Butman 1989) and, on a fine scale (Eckman 1975), be deposited on the bottom in patterns controlled by the physics of marine snow deposition.

On a larger scale, larval polychaete settlement might be controlled by the production of marine snow, its vertical flux through the water column, and whether the physics of the benthic boundary layer is conducive to the deposition of aggregates. Perhaps periods of mass flocculation of phytoplankton (Smetacek 1985, Krank \& Milligan 1988, Alldredge \& Gotschalk 1989) and subsequent deposition of the phytoplankton aggregates on the bottom (Billet et al. 1983, Lampitt 1985, Riemann 1989, Lampitt 1996) are also periods of high settlement of larval polychaetes. Deposition of larval polychaetes on the bottom during phytoplankton sedimentation events would have the added advantage for the larvae of a large benthic food supply, the settled phytoplankton.

Another possible reason why larval polychaetes associate with marine snow may be that they are investigating aggregates as potential settlement sites. Often the surface of the muddy benthos is covered with a layer of flocculent material. Deposited marine snow is probably a major component of such benthic flocculent layers 
(Lampitt 1996). Because of the similarity between marine snow and the benthic flocculent layer, larval polychaetes contacting an aggregate may initially perceive it as the benthos. The aggregate might be investigated as a potential settlement site and, if rejected, the larvae would move on, but if the larvae perceives the aggregate as the benthos settlement might occur

In the laboratory experiments, all of the Arenicola cristata in the marine snow samples had built tubes in the aggregates; in essence they had settled in the aggregates. In contrast, none of the $A$. cristata in the aggregate-free surrounding water were found in tubes. Tube formation was perhaps triggered by something in the marine snow. Likewise, A. cristata from aggregates sampled in the field were also found in tubes. Perhaps for A. cristata marine snow is indistinguishable from a benthic settlement site.

Larval polychaetes are strongly associated with marine snow. Other common meroplankters (e.g. larval echinoderms) are seldom found on aggregates (A.L.S, unpubl. data). The remarkably strong association of polychaete larvae, especially competent larvae, with marine snow makes us suspect that adaptation to life on or in aggregates may have been a factor contributing to the evolution of larval polychaete morphology and behavior. Because of ventral neurotrochs and a wormish shape, many larval polychaetes are capable of gliding across surfaces long before they actually settle to the bottom. Perhaps this seemly precocious capacity to crawl on hard substrates is an adaptation to life on aggregates. Some larval types, those with large palps (e.g. spionids), seem well designed to feed on surfaces. Again, perhaps this represents an adaptation to feeding on the benthic-like habitat of aggregates long before the larvae actually settles to the benthos. A realization of the role marine snow plays in the pelagic existence of many types of larval polychaetes may assist us in better understanding the forces which have driven the evolution of this group.

Acknowledgements. This research was supported by NSF Grant OCE9017807 Field assistance was provided by $G$. Reikerk, M. Williams, M. Reeder and E. Larson. Helpful comments on the manuscript were provided by B. Pernet. Field work in the San Juan Islands was greatly facilitated by the help of the faculty and staff of the Friday Harbor Laboratories, University of Washington. This is a contribution from the Oregon Institute of Marine Biology, University of Oregon.

\section{LITERATURE CITED}

Alldredge AL (1976) Discarded appendicularian houses as sources of food, surface habitats, and particulate organic matter in planktonic environments. Limnol Oceanogr 21: $14-23$

AIldredge A.L, Gotschalk CC (1988) In situ settling behavor of marine snow. Limnol Oceanogr 33:339-351
Alldredge AL, Gotschalk CC (1989) Direct observations of the mass flocculation of diatom blooms: characteristics, settling velocities, and formation of dratom aggregates. Deep Sea Res 36:159-17 1

Alldredge AL, Silver MW (1988) Characteristics, dynamics and significance of marme snow. Prog Oceanogr 20:41-82

Alldredge AL, Youngbluth MJ (1985) The significance of macroscopic aggregates (marjne snow) as sites for heterotrophic bacterial production in the mesopelagic zone of the subtropical Atlantic. Deep Sea Res 32:1445-1456

Asper $V$ (1986) Measuring the flux and sinking speed of marine snow aggregates. Deep Sea Res 34:1-18

Beers JR, Trent JD, Reid FMH, Shanks AL (1986) Macroaggregates and their phytoplanktonic components in the Southern California Bight. J Plankton Res 8:475-487

Bhaud $M_{1}$ Cazaux $C$ (1987) Description and identification of polychaete larvae; their implications in current biological problems. Oceanis 13:596-753

Billet DSM, Lampitt RS, Rice AL, Mantoura RFC (1983) Seasonal sedimentation of phytoplankton to the deep-sea benthos. Nature 302:520-522

Bochdansky AB, Herndl GJ (1992) Ecology of amorphous aggregations (marine snow) in the Northern Adriatic Sea. liI. Zooplankton interactions with marine snow. Mar Ecol Prog Ser 87:135-146

Butman CA (1989) Sediment-trap experiments on the importance of hydrodynamical processes in distributing settling invertebraie larvae in near-botrom waters. J exp Mar Biol Ecol 134:37-88

Caron DA, Davis PG, Madin LP, Sieburth JM (1983) Heterotrophic bacteria and bacterivorous protozoa in oceanic macroaggregates. Science 318:795-797

Davoll PJ, Silver MW (1986) Marine snow aggregates: life history sequence and microbial community of abandoned larvacean houses from Monterey Bay, California. Mar Ecol Prog Ser 33:111-120

Eckman JE (1975) Small-scale patterns and processes in a soft-substratum, intertidal community. J Mar Res 37: $437-457$

Green EP, Dagg MJ (1997) Mesozooplankton associations with medium to large marine snow aggregates in the northern Gulf of Mexico. J Plankton Res 19:435-447

Grossart HP, Simon M (1993) Limnetic macroscopic organic aggregates (lake snow): Occurrence, characteristics, and microbial dynamics in Lake Constance. Limnol Oceanogr 38:532-546

Hamner WM, Madin LP, Alldredge AL, Gilmer RW, Hamner PP (1975) Underwater observations of gelatınous zooplankton: sampling problems, feeding biology, and behav10r. Limnol Oceanogr 20:907-917

Herndl GJ (1992) Marine snow in the Northern Adriatic Sea Possible causes and consequences for a shallow ecosys tem. Mar Microb Food Webs 6:149-172

Honjo S, Doherty K, Agrawal YC, Asper VL (1984) Direct optjcal assessment of large amorphous aggregates (manne snow) in the deep ocean. Deep Sea Res 31:67-76

Kiørboe T (1996) Material flux in the water column. In: Barker $B$, Jorgensen K, Richardson $K$ (eds) Eutrophication in coastal marine ecosystems. Coastal Estuarine Stud 52: $67-94$

Kiørboe T, Andersen KP, Dam HG (1990) Coagulation efficiency and aggregate formation in marine phytoplankton. Mar Biol 107:235-245

Krank K, Mulligan TG (1988) Macroflocs from diatoms: in situ photography of particles in Bedford Basin, Nova Scotia. Mar Ecol Prog Ser 44:183-189

Lampitt RS (1985) Evidence for the seasonal deposition of 
detritus for the deep-sea floor and its subsequent resuspension. Deep Sea Res 32:885-897

Lampitt RS (1996) Snow falls in the open ocean. In: Summerhays CP. Thorpe SA. (eds) Oceanography. John Wiley \& Sons, New York, p 96-112

Larson ET, Shanks AL (1996) Consumption of marine snow by two species of juvenile mullet and its contribution to their growth. Mar Ecol Prog Ser 130:19-28

Omori M. Hamner WM (1982) Patchy distribution of zooplankton: behavior, population assessment and sampling problems. Mar Biol 72:193-200

Omori M, Ikeda T (1984) Methods in marine zooplankton ecology. John Wiley \& Sons, New York

Rasmussen E (1973) Systematics and ecology of the Isefjord marine fauna (Denmark). Ophelia 11:1-495

Riebesell U (1989) Comparison of sinking and sedimentation rate measurements in a diatom winter/spring bloom. Mar Ecol Prog Ser 54:109-119

Riemann F (1989) Gelatinous phytoplankton detritus aggregates on the Atlantic deep-sea bed; structure and mode of formation. Mar Biol 100:533-539

Shanks AL, Edmondson EW (1990) Vertical flux of metazoans (holoplankton, meiofauna, and larval invertebrates) due to their association with marine snow. Limnol Oceanogr 35 : $455 \cdots 463$

Shanks AL, Trent JD (1980) Marıne snow: sinking rates and potential role in vertical flux. Deep Sea Res 27:137-144

Shanks AL, Walters K (1996) Feeding by a heterotrophic dinoflagellate (Noctiluca scintillans) in marine snow. Limnol Oceanogr 41:131-145

Silver MW, Shanks AL, Trent JD (1978) Marine snow: micro-

This article was submitted to the editor plankton habitat and source of small-scale patchiness in pelagic populations. Science 201:371-373

Smetacek VS (1985) Role of sinking in diatom life-history cycles: ecological, evolutionary and geological signuficance. Mar Biol 84:239-251

Strathmann MF (1987) Reproduction and development of marine invertebrates of the northern Pacific Coast. University of Washington Press, Seattle

Suh HL, Toda T, Terazaki M (1991) Diet of calyptopes of the euphausid Euphausia pacifica in the Yellow Sea. Mar Biol $111: 45-48$

Suzuki N, Kato K (1953) Studies on suspended materials marine snow in the sea. Part I. Sources of marine snow. Bull Fac Fish Hokkaido Univ 4:132-135

Syvitski JPM, Asprey KW, Leblanc KWG (1995) In situ characteristics of particles settlıng " ithin a deep-water estuary. Deep Sea Res 42:223-256

Thorson G (1946) Reproduction and larval development of Danish marine bottom invertebrates, with special reference to the planktonic larvae in the Sound (Oresund). Medd Dan Fisk Havunders Ser Plankton 4:1-523

Tsujita $T$ (1952) A preliminary study on naturally occurring suspended organic matter in waters adjacent to Japan. J Oceanogr Soc Jpn 8:113-126

Walsh ID, Gardner WD (1992) A comparison of aggregate profiles with sediment trap fluxes. Deep Sea Res 39 $1817-1834$

Wells JT, Shanks AL (1987) Observations and geologic significance of marine snow in a shallow-water, partially enclosed marine embayment. J Geophys Res 92 $13185-13190$

Manuscript received: January 27, 1997

Revised version accepted: May 21, 1997 